\title{
The Ratu Boko Mantra And The Sailendras
}

\section{Roy Jordan and Brian Colless}

Keywords: temple, hindu-buddha, kingdom, wangsa, ruler, cultural context, inscription

\section{How to Cite:}

Jordaan, R., \& Colless, B. (2004). The Ratu Boko Mantra And The Sailendras. Berkala Arkeologi, 24(1), 56-64. https://doi.org/10.30883/jba.v24i1.894

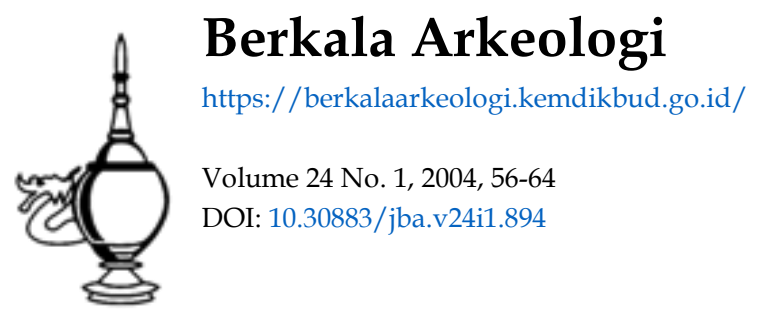

\section{c) (i) (5)}

This work is licensed under a Creative Commons Attribution-NonCommercial-ShareAlike 4.0 International License. 


\section{THE RATU BOKO MANTRA AND THE SAILENDRAS}

\section{Roy Jordaan and Brian Colless}

7 he Ratu Boko (or Ratu Båkå) plateau, near Yogyakarta in southern central Java, is surrounded by an impressive array of Hindu and Buddhist shrines.

1 Notable among these are the Prambanan temples to the north, and Candi Kalasan to the west, with the massive Borobudur stupa 40 kilometres to the northwest, and the lofty volcanoes Merapi and Merbabu towering over the northern landscape. The presence of dynamic mountains and Buddhist monuments makes the Ratu Boko heights an ideal spot for locating the lost palace of the Śailendra 'mountain lords', though they may well have resided on the plain or in a northern port (Jordaan 1996:19-23). However that may be, Ratu Boko was the site of the famous Śailendra monastery, Abhayagirivihāra, which had links with Sri Lanka (de Casparis 1961; Lokesh Chandra 1986).

New information on the Sailendras is always welcome, and Jeffrey Sundberg (2003) has highlighted a significant piece of evidence from Ratu Boko: a mantra inscribed four times on a piece of gold foil, which was discovered near the western entrancegate (of the monastery) by Suhamir, who made a hand-drawn facsimile (Suhamir 1950:34). Regrettably, the gold foil itself has disappeared, preventing us from checking Suhamir's transcription and determining the physical dimensions of the object.

The gold foil was cut or snipped into two connected diamond-shaped leaves, apparently giving it the form of a tantric vajra, and this tends to confirm that its inscription is a tantric Buddhist text. On the back and front of each of the leaves the same mantra, 'om taki hüm jah svāhä', is inscribed in Old Javanese characters. The two copies of the mantra on the reverse side display a scribal oddity: within the exaggerated bubble of the vowel ' $i$ ' there are a further two curved lines comprising the characters 'panarabwan' and 'khanipas' (or, perhaps, 'hanipas'). Aecording to Kusen (1994), who was the first to pay attention to Suhamir's note, the word hanipas might derive from the verb tipas, meaning 'to store' or 'lay away', and he argued that the composition could therefore be glossed as 'panarbwan [who] stored [the mantraplate]'. He further suggested that if panarbwan can be identified with Rake Panaraban, then the Rake of Panaraban was the one who deposited the gold foil near the entrance-gate, and this could mean that at the time when Rake Panangkaran was building the Abhayagirivihāra the Rake Panaraban had assisted in the construction of the main gate of this complex (Kusen 1994:85). 
In Sundberg's article, attention is first focussed on the textual source and the meaning of the Ratu Boko mantra. The author relates how, 'after a substantial amount of directed browsing through various categories of Mahāyāna and Buddhist tantric literature', his persistent search for the textual source of the mantra was finally rewarded with the discovery of a possible variant, 'hüm takkijjah', in the well-known myth of Trailokyavijaya in the second section of the Sarva Tathägata Tattva Sangraha ('The Symposium of the Reality of All Tathāgata', hereafter abbreviated as STTS), the root text of the category of Buddhist literature known as the Yoga Tantra in Tibet. In the STTS the said mantra is referred to as 'the All Tathāgata's ElephantGoad of Summoning' (sarva-tathägata-samayānkusan/vajrānkuśan) and as hrdaya ('personal or quintessence spell of a divinity') of the bodhisattva Vajrapāni. With this magical formula the wicked god Maheśvara (Śiva) and his retinue of Hindu gods and goddesses were subdued in order to be incorporated into a Buddhist mandala. In the myth of Trailokyavijaya, which need not be retold here, Maheśvara is verbally resisting his intended subjugation, calling Vajrapāni 'a little yaksa', whereupon he is killed, revived, trampled upon, and humiliated, but eventually being graciously permitted by Vajrapāni to be reborn as a Tathāgata bearing the name Bhasmeśvaranirghosa (Soundless Lord of Ashes). In gratitude, Mahādeva then exclaims: 'The marvelous wisdom of all the Buddhas! Trampled under the feet of a yaksa, one is raised up in nirvāna!'

Sundberg argues that the exact form of the Ratu Boko mantra could possibly be traced to an older source than the Nepalese Sanskrit manuscript of the STTS (BroughSnellgrove edition), in which he had found it. In support of this contention he refers to the research of other scholars indicating the existence of earlier Chinese and Japanese translations and summaries of the Trailokyavijaya text, as a result of the efforts of famous seventh-century translators such as Vajrabodhi and Amoghavajra, who had sailed through the Straits of Malacca on their way to the Far East from India and Sri Lanka, and had visited Sumatra and possibly Java. Hence, Sundberg's statement that 'the direct connection between the Indian and the Javanese Buddhists is sufficiently firm for us to disbelieve that the Javanese remained in ignorance of the STTS as a whole and composite work'.

As regards the meaning and consequences of the mantra, Sundberg explains that the 'Hüm takkijjah' mantra is known by the remarkable name of 'Disciplinary Elephantgoad Spell of All the Tathagatas' from its symbolic use as a 'hook', 'goad' or 'prod' for summoning, for compulsion, for convocation, the utterance of which forcibly transported Siva to the Andamantine Jeweled Palace at the peak of Mount Semeru. Here, as said, Maheśvara was subsequently manipulated with other mantras until he was prepared to be incorporated into the Buddhist mandala of Vajrapāni. Sundberg correctly notes that 'this power of compulsion or of summoning is sine qua non for 
the Mantrayanist' (2003:173), and thinks that the Ratu Boko mantra furnishes clear proof of the influence of Tantric Buddhism in Śailendra-era Java: "Given Panarabwan's acquaintance with this material at a datable early phase in Javanese history as well as the 782 Śailendra inscription of Kelurak, a tantric work of uncertain ideological provenance which also subordinates the three Hindu supreme gods to a Buddhist deity, we may safely say that the grounds are open to find expression of these tantric convictions in the stone temples of Java' (2003:181).

Let us now turn to the identity of Panarbwan. As did Kusen before him, Sundberg considers the panarbwan in the mantra to be a variant of the name of the third monarch in the Wanua Tengah IIl kinglist, namely Rake Panaraban (784-803), the successor of Panangkaran. In addition to the phonetic and orthographic arguments, Sundberg states that the architectural milieu also renders this identification plausible. He recalls the fact that Panaraban's predecessor, the Rake of Panangkaran, was involved in the construction of the Tārā temple of Kalasan, easily visible from the Ratu Boko heights, and also that the temple complex of Candi Sewu and the Śailendra monastery for the Sinhalese monks of Abhayagiri were built respectively in the vicinity and on top of the Ratu Boko heights. Thus, says Sundberg, 'It is clear that the immediate surroundings of the Ratu Baka hill were a hive of Buddhist building activity at the time that Panaraban came to his throne in 784 A.D., and it should be no surprise that our Panarbwan should continue this architectural activity with the erection of the immense gates which are the tallest features on the plateau'. Decisive for the identification of Panarbwan with Rake Panaraban is the fact that 'an instance of the name Panaraban/Panarabban/Panarbwan is unknown from any other source and the circle of people who would be priviliged with the right of depositing Buddhist memorabilia would also be very small, likely consisting of only the royal family and the foremost of Buddhist ecclessiastics'(2003:175). But Sundberg goes further by concluding that Panaraban can be no other than Samaratungga, the Sailendra ruler under whose auspices the 792 Buddhist inscription of Abhayagirivihãra was composed. He declares: 'Not only does this conclusion accord with the coincidence and cotemporality of Panaraban and Samaratungga on the heights of the Ratu Baka in the period around 790, but seems to derive also from the nature of the Great Gate and its endowment. Accepting the manifest Śailendra suzerainty over the plains of Prambanan during this time, how could the king Samaratungga allow the king Panarabwan to construct not only the tallest feature of the plateau but also a feature under which the great Śailendra mahārāja would have to pass to access the escarpment and his vihära? On the grounds of royal protocol alone, we must suspect that the Raka of Panarban was the member of the Śailendra dynasty bearing the consecration name Samaratungga, and that therefore members of the Śailendra dynasty were folded into the lineage of kings commemorated in the inscriptions of Mantyāsih and chronicled in Wanua Tengah III. I therefore believe that Panangkaran (reigned 746-784) was the Buddhist king reputed as the 'Killer of Haughty Enemies', that Panarabwan (784-803) 
was Samaratungga, and that Warak (803-827) was perhaps - the evidence is circumstantial and would require many pages to argue - the child known as Bālaputradeva whose vihära at Nālandā was benefacted by a king of the Pāla dynasty'(2003:175-176).

Let us start with the last identification and try to establish the reasons why the identity of Warak and Bālaputra should require so many pages to argue. A crucial problem, undoubtedly, is the current dating of the Nālandā inscription as of about 860 , which Jordaan (2000a) has revised to about 850 , but which is still too far removed from the last year of Warak's reign in 827. Of course, it cannot be excluded that our new dating, which we had deliberately estimated conservatively, is not correct and should perhaps be fixed at an even earlier date. Yet without the evidence from Pāla inscriptions to confirm this hypothetical earlier dating we have to dismiss Sundberg's identification of Warak with Bālaputra. With respect to his other identification of Panarabwan with Samaratungga, we must observe that it is irreconcilable with the accepted dating of the Karengtěngah (Kayuwumgan) inscription as of 824, the year in which Samaratungga and his daughter Prāmodavardhanī were involved in the inauguration of a Buddhist temple. To our knowledge, so far no scholar has questioned this date, which is the same as that in the Old Javanese part on the reverse side of the stela, which was issued by the Rakai of Patapan. In light of this conflicting evidence we must also dismiss the second identification. Since Sundberg does not elaborate upon his first identification, we cannot tell what firm evidence he has at his disposal to demonstrate Panangkaran's identity with the king who is designated as the 'Killer of Mighty Foes', whose coronation name probably was Śrī Sangrāmadhanamjaya. Suffice to say that coincidence and cotemporaneity are a necessary but insufficient condition for accepting this identification, or any other for that matter.

But what, it could be retorted, about the religious and socio-political arguments which Sundberg with so much skill and conviction has mustered in support of Rake Panarabwan's identity with Samaratungga? To be able to evaluate their validity and tenability we must take a closer look at these arguments. The first thing to notice is that Sundberg, as did Kusen earlier, assumes the gold foil to be part of a foundation deposit related to the construction of the great western entrance-gate of the Ratu Boko complex. It is doubtful whether this is a correct assumption. In the admittedly terse excavation report by Suhamir, from which Sundberg correctly quotes, it is stated that 'during the excavation of the remains of the big retaining wall in front of the first gate a small gold plate was found, having the form of two interrelated diamonds [which were] inscribed on either side'. Noticing that 'in front of the first gate stands not a retaining wall but a ramp leading down from it', Sundberg says that 'we must presume in the absence of better information that the mantra was found closer rather than farther from the first gate, possibly in the steps or ramp leading up to it' (2003:165). 
Closer inspection of Suhamir's (1950:34) sketchy map of the Ratu Boko site, that is to say of 'the situation of the layout of the gate and surroundings', indeed shows the presence of a ramp in front of the first gate, but it also shows that the ramp was built in a recess of the wall surrounding the first terrace. In the legend (1950:35) Suhamir refers to this wall in Dutch as buitenste terrasmuur, that is 'outer terrace wall'. Today, little is left of this retaining wall (hence Suhamir's use of the word 'remains'), because the first terrace has partly collapsed and in several places has become one indistinguishable whole with the sloping hill on which it was built. In view of these circumstances we think it more likely that the gold foil was discovered in the area inbetween the first gate and the ramp rather than in the steps of the gate or ramp. There is no evidence that the gold-plate was part of a foundation deposit, because it was found loose and not laid away in a stone box (pripih) as is the case with foundation deposits.

Sundberg himself provides yet another reason to dismiss the idea of a foundation deposit. With characteristic open-mindedness, Sundberg reports in a footnote that 'in response to an early draft of this essay, David Snellgrove noted that he expected that a loose gold leaf mantra of this type would be associated with a statue rather than a building' (2003:178. n.29). In the main text of his article Sundberg admits to being 'particularly attracted to the notion of the establishment of a mandala of statues, long since disappeared, on the great terrace of the Ratu Baka' (2003:178). In support of this hypothesis he invokes two witnesses. First, Lokesh Chandra, who inferred the existence of a large statue of Avalokiteśvara from his study of the Abhayagirivihära inscription. Second, Suhamir: 'There is some archaeological evidence for the possibility that statuary was erected on the primary terrace, for in the very paragraph of Suhamir's report which follows his report of the excavation of the mantra, he notes (1948:37) that an iron sword of length $60-70 \mathrm{~cm}$, including handle, "of a type which is depicted in ancient Javanese reliefs as an attribute of a god", as well as an iron daggerhead, were found by a villager in the field near the so-called 'kraton' [palace] of the Ratu Baka' (Sundberg 2003:178-179).

If, therefore, we dismiss the idea that the gold foil was part of a foundation deposit, we have also removed the basis of Sundberg's theory about Panangkaran's involvement in the construction of the first gate, and with it the validity of his otherwise persuasive argument about Javanese royal protocol and the far-reaching implications for our understanding of the political situation in Śailendra-era Java.

Pace Sundberg, there is no convincing evidence that Panaraban had built the Śailendra monastery on the Ratu Boko plateau, even if it were true that the monastery was built during his reign. As said, contemporaneity is a necessary, but insufficient condition for assuming the identity of Panaraban with Samaratungga. Actually, we cannot even be sure that Panaraban and his predecessor, the Rakai of Panangkaran, adhered to 
Buddhism. Sundberg does not seem to realize that his claim about the latter's religious afffiliation is based on a questionable presupposition, namely that Panangkaran's Buddhism is demonstrated by his involvement in the construction of the Tārā temple of Kalasan and his benefactory land donations for the vihära at Pikatan as documented in the inscription of Wanua Tengah III. Sundberg alleges that the building of the Tārä temple was conceived and executed by Panangkaran, but fails to adduce evidence for this claim, except to note that the idea is in consonance with Lokesh Chandra's $(1995: 217)$ interpretation of the Kalasan inscription. We, on the other hand, subscribe to the interpretation of Van Naerssen (1947) and Bosch (1952) who think that the construction of the Tārā temple was initiated by the Śailendras, and that the involvement of Panangkaran was limited to the disposal of land and labour. As foreigners the Śailendras simply had no say in these matters. Benefactory land donations of land as such are insufficient to determine the religious affiliation of Panangkaran, the only conclusion that can be safely drawn from his donations is that Panangkaran was not unfavourably disposed toward Buddhism. Numerous examples could be given, from Java and abroad, of Hindu rulers supporting the Buddhist cause, and the reverse (Jordaan 2000b).

An important consideration for rejecting the hypothesis of Panaraban's adherence to Buddhism is Sundberg's failure to explain the reason why Panarabwan had his name inserted in the inscription. Sundberg merely assumes that Panarabwan 'by inscribing his name within the dot of the ' $\mathrm{i}$ ', has infixed his name as a vital component of the sacred mantra. In this way, he is operating within the circumference of the mystic vowel itself, and clearly intends to link himself to the mantra or the cosmic being it points to, albeit in a manner we cannot understand'(2003:177). Sundberg ventures to say that 'no definite answer may ever be found for the question of why Panarabwan chose to embed this particular mantra near the gate leading up to the Ratu Baka plateau' (2003:177), but we think that there is a plausible solution for this mystery provided that we renounce the idea that Panaraban was a Buddhist and himself responsible for the insertion of his name in the mantra, since for the latter there is no evidence at all. If Panaraban did not have his name inscribed in the gold foil, there remains, as Sundberg himself recognized, another option, namely 'the foremost of Buddhist ecclesiastics' of the Śailendra monastery of Ratu Boko. Assuming with Snellgrove that the loose gold foil was associated with a statue rather than a building, an apt piece of statuary, in line with the myth of Trailokyavijaya, would be a representation of Maheśvara being subdued by Vajrapāni. The intention could have been the mantrical subjugation and conversion of Panaraban. As is stated in Sundberg's quote from Snellgrove: 'All tantras claim the power to coerce divinities, for it is by coercing them into an image or symbol that one is enabled to worship them and make them suitable offerings, and it is by coercing them into oneself that one is enabled to act with their assumed assurance ... and thus achieve the objective in view' (2003:173). Thus, by infixing Panarabwan's name into the same mantra that was used 
to subjugate Siva in the myth of Trailokyavijaya the monks sought to establish a similar coercive hold over Panarabwan. This interpretation accords with the use by Indologists of the designation 'conversion myth' for the Trailokyavijaya myth, which fits our assumption that Panarabwan was a Śaiva king. Other elements could be drawn upon to strengthen this symbolic transposition, such as the comparison of the Ratu Boko heights with the top of Mount Semeru, the encircling of Panarabwan's name to convey the idea of his being caught and tied up with ropes and rendered powerless.

Yet, it seems that there were more things at stake than the mere subjugation of Panarabwan. As pointed out by Sundberg, 'the vajränkuśa, symbol of the first summoning rite in the performance of a tantric ritual, is associated with the eastern gate, the proper place to begin the pradaksina of the mandala, while the western gate is associated with the fetter. Therefore, it is the eastern rather than the western side of a mandala which is appropriate for the summoning implied by the mantra'(2003:179). Sundberg then asks whether the find-spot of the mantra near the western gate should not be related to the nearby cremation pit, also because it appears from the tantric literature that Vajrapāni has not just the power over death and destruction, but also of revification. 'In this context', he continues, 'the benedictory nature of the mantra makes more sense and furthermore might better accord with the westward orientation of the gate and the west-ward opening cremation temple: the West is the direction of death and the dying of the sun, and it is Vajrapanni who might be supplicated to amend the unwanted passing away of a life'(2003:179). In Sundberg's opinion, only three candidates were entitled to this special treatment, namely Sañjaya, Panangkaran, or Panarabwan himself. Sundberg favours Panangkaran because of his donations to the cause of Buddhism, and also because he cannot imagine Panarabwan performing a kind of 'do-it-yourself resurrection' with this mantra. In our opinion, however, the last argument is not quite intelligible nor convincing. We must agree with the anonymous referee of Sundberg's article, that it cannot be excluded that Panarabwan himself was the deceased who was cremated on the plateau, and that the Sailendras and the Buddhist clergy were involved in his funerary ceremony. Sundberg evaluates this possibility as follows: 'One referee of this paper offered the interesting suggestion that if the Ratu Baka mantra was to be taken as a Buddhist memento mori, that [then] perhaps it was the Śailendras who buried a Hindu Panarabwan. The anti-Śaiva nature of the mantra suggests to me that such a rude choice of the text by the Sailendras would be an insult rather than a boon for the deceased (2003:183, n.42). But Sundberg here emphasizes the anti-Śaiva nature of the mantra, in contrast to his earlier remarks about its benedictory character. We must also object to his use of the designation memento mori, for the mantra in question undoubtedly was but an opening formula in a more elaborate and complex ritual of post-terminal care, having as its ultimate goal the resurrection of the dead person and his entrance into nirvana. Had not Śiva himself recognized that the humiliation had a purpose, saying that by being trampled upon under the feet of a yaksa, one is raised up in nirvāna? 


\section{Note}

Originally, this short review on Jeffrey Sundberg's (2003) article was meant to be included as an appendix in a forthcoming book, entitled The Mahāräjas of the Isles (Jordaan and Colless, in press), but since the book is focussed on the Śailendras and the so-called problem of Sriwijaya it was decided to publish this commentary. separately.

\section{REFERENCES}

Bosch, F.D.K.

'Çrīijaya, de Çailendra- en de Sañjayavamça', Bijdragen tot de Taal-, Landen Volkenkunde 108:113-123, 1952

Casparis, G.J. de

'New evidence on cultural relations between Java and Ceylon in ancient times', Artibus Asiae 24:241-248, 1961

Chandra, Lokesh

'Cultural contacts of Indonesia and Sri Lanka in the eighth century and their bearing on the Barabudur', Journal of the Asiatic Society 28:38-56.

1995 Cultural Horizons of India. Vol.4: Studies in Tantra and Buddhism, art and archaeology, language and literature. New Delhi: International Academy of Indian Culture and Aditya Prakashan. [Satapitaka Series 381.], 1986

Jordaan, Roy E.

'Candi Prambanan: an updated introduction', in Roy E. Jordaan (ed.) In praise of Prambanan; Dutch essays on the Loro Jonggrang temple complex, pp. 3-115, Leiden: KITLV Press, 1996

'Pāla chronology, the dating of the Nālandā inscription, and the end of Śailendra rule in Java', Paper presented at the $8^{\text {th }}$ International conference of the European Association of Southeast Asian Archaeologists, Sarteano (Tuscany), Italy, 2-6 October 2000, 2000a 
'Co-existence of religions in ancient Central Java', in Lokesh Chandra (ed.), Society and culture in Southeast Asia: continuities and changes, pp.121-126, New Delhi: Aditya Prakashan, 2000b

Jordaan, Roy E. and Brian E.Colless

n.d. The Mahäräjas of the Isles; The Sailendras and the problem of Sriwijaya. Leiden: Universiteit Leiden. [Semaian, in press.]

Naerssen, F.H. van

'The Çailendra interregnum', in: India antiqua, pp. 249-253, Leiden: Brill, 1947.

Suhamir

'Verslag van de werkzaamheden van de voormalige Bouwkundige Afdeling van de Oudheidkundige Dienst van 8 maart 1942 tot 19 december 1948', Oudheidkundig Verslag 1948, Bijlage A, pp. 20-24, Bandung: Nix, 1950

Sundberg, Jeffrey Roger

'A Buddhist mantra recovered from the Ratu Baka plateau; A preliminary study of its implications for Śailendra-era Java', Bijdragen tot de Taal-, Landen Volkenkunde 159(1):163-184, 2003 